Article

\title{
Cytotoxic Activity of Piper cubeba Extract in Breast Cancer Cell Lines
}

\section{Potchanapond Graidist ${ }^{1,2, *}$, Mananya Martla $^{1}$ and Yaowapa Sukpondma ${ }^{3}$}

1 Department of Biomedical Sciences, Faculty of Medicine, Prince of Songkla University, Hat Yai, Songkhla 90110, Thailand; E-Mail: mmananya@gmail.com

2 The Cancer Molecular Biology Excellence Research Laboratory, Prince of Songkla University, Hat Yai, Songkhla 90110, Thailand

3 Department of Chemistry, Faculty of Science, Prince of Songkla University, Hat Yai, Songkhla 90110, Thailand; E-Mail: yaowapa.suk@psu.ac.th

* Author to whom correspondence should be addressed; E-Mail: gpotchan@medicine.psu.ac.th; Tel.: +66-74-451-184; Fax: +66-74-429-584.

Received: 23 January 2015 / Accepted: 6 April 2015 /Published: 10 April 2015

Abstract: This study aimed to evaluate the cytotoxicity of a crude extract of Piper cubeba against normal and breast cancer cell lines. To prepare the extract, $P$. cubeba seeds were ground, soaked in methanol and dichloromethane and isolated by column chromatography. Fractions were tested for cytotoxicity effects on normal fibroblast (L929), normal breast (MCF-12A) and breast cancer cell lines (MCF-7, MDA-MB-468 and MDA-MB-231). The most effective fraction was selected for DNA fragmentation assay to detect apoptotic activity. The results showed that the methanolic crude extract had a higher cytotoxic activity against MDA-MB-468 and MCF-7 than a dichloromethane crude extract. Then, the methanolic crude extract was separated into six fractions, designated A to F. Fraction C was highly active against breast cancer cell lines with an $\mathrm{IC}_{50}$ value less than $4 \mu \mathrm{g} / \mathrm{mL}$. Therefore, Fraction $C$ was further separated into seven fractions, CA to CG. The ${ }^{1} \mathrm{H}-\mathrm{NMR}$ profile showed that Fraction CE was long chain hydrocarbons. Moreover, Fraction CE demonstrated the highest activity against MCF-7 cells with an IC50 value of $2.69 \pm 0.09 \mu \mathrm{g} / \mathrm{mL}$ and lower cytotoxicity against normal fibroblast L929 cells with an IC50 value of $4.17 \pm 0.77 \mu \mathrm{g} / \mathrm{mL}$. Finally, DNA fragmentation with a ladder pattern characteristic of apoptosis was observed in MCF-7, MDA-MB-468, MDA-MB-231 and L929 cells, but not in MCF-12A cells. 
Keywords: Piper cubeba; cytotoxicity; breast cancer; DNA fragmentation; apoptosis

\section{Introduction}

Cancer is a major public health problem in the world. Breast cancer is the second leading cause of cancer deaths among women in the United States [1]. Chemotherapy is one of the commonly-used strategies in breast cancer treatment. This therapy is usually associated with adverse side effects, ranging from nausea to bone marrow failure [2] and development of multidrug resistance (MDR) [3]. Therefore, finding natural compounds from plants may provide an alternative cancer treatment.

In the last few decades, scientists have studied many biological properties of a number of promising plants and herbs. Piper cubeba L., or tailed pepper, is a plant in the family Piperaceae, genus Piper. This plant is a folkloric plant and has been used as a spice in many countries, including Indonesia, India, Europe (in the Middle Ages) and Morocco. The fruit has also been used for the treatment of dysentery, syphilis, gonorrhea, abdominal pain, diarrhea, enteritis and asthma [4]. P. cubeba has been used in Unani medicine as a protective and curative agent in various renal diseases [5]. Extracts of $P$. cubeba have various biological activities, including anti-inflammatory [6,7], anti-type IV allergic [6], anti-leishmanial [8], genotoxic [9], anti-proliferative [10] and anti-hepatitis C virus [11]. Dried P. cubeba contains alkaloids, lignans and terpenoids (an essential oil) [12]. Nahak and Sahu reported that P. cubeba ethanol crude extract has a higher antioxidant activity than the extract from another Piper species, $P$. nigrum extract, which could be due to a polyphenol compound. $P$. cubeba has a phenolic content which is higher than $P$. nigrum [13]. Thirteen lignans have been found in the dried fruit. Furanofuran lignans, such as cubebin, hinokinin, yatein and isoyatein are common lignans that are found in the plant genus Piper and also appear as a major lignans in the dried fruit of $P$. cubeba [14]. Cubebin is known to possess anti-inflammatory, analgesic [15] and anti-microbial activities [16], as well as antioxidants [17].

The aim of this present work was to determine the cytotoxic effect of $P$. cubeba crude extract on normal fibroblast (L929), normal breast (MCF-12A) and three breast cancer cell lines (MCF-7, MDA-MB-468 and MDA-MB 231). Our results showed that the Fraction CE showed a cytotoxic effect on breast cancer cell lines, and its mechanism of action seemed to include the induction of apoptosis.

\section{Experimental Section}

\subsection{Plant Material Extraction and Isolation}

P. cubeba seeds were acquired from Songkhla province, Thailand. Plant specimens were identified and deposited in the herbarium at the Southern Centre of Thai Traditional Medicine, Department of Pharmacognosy and Pharmaceutical Botany, Prince of Songkla University, Thailand (voucher specimen Number SKP146160302). The seeds were ground and soaked in methanol and dichloromethane for $72 \mathrm{~h}$. The extract was then filtered, dried on a rotary evaporator at $45^{\circ} \mathrm{C}$, under reduced pressure. The methanolic crude extract from $P$. cubeba (33.64 grams) was separated by column chromatography on silica gel (Merck Kiesegel 60) and eluted with increasing proportions of hexane, dichloromethane and methanol. Fractions that had similar profiles on the TLC plates were pooled. 


\subsection{TLC Analysis}

Thin-layer chromatography (TLC) was performed on silica gel GF256 (Merck). Samples of each fraction were spotted on a TLC plate. The TLC plate was developed in a beaker or closed jar. Then, a small amount of mobile phase was placed in the container. In this experiment, the solvents used as a mobile phase were hexane, dichloromethane and methanol. Fractions were separated by column chromatography and were analyzed. The same compounds were pooled and tested for any cytotoxic effects. Then, potential crude extracts were analyzed by ${ }^{1} \mathrm{H}-\mathrm{NMR}$ technique, and spectra were recorded in $\mathrm{CDCl}_{3}$ on a 300-MHz spectrometer (Avance 300, Bruker, Germany).

\subsection{Cell Culture Conditions}

Three breast cancer cell lines (MCF-7, MDA-MB-231, MDA-MB-468) and a normal breast cell line (MCF-12A) were obtained from ATCC (Manassas, VA, USA). Normal fibroblast cells (L929) were provided by Assoc. Prof. Dr. Jasadee Kaewsrichan (Faculty of Pharmaceutical Sciences, Prince of Songkla University, Thailand). MCF-7 cells were grown in RPMI 1640 (Invitrogen). MDA-MB-231, MDA-MB-468 and L929 cells were grown in DMEM (Invitrogen). Each medium contained 10\% fetal bovine serum (Invitrogen) supplemented with 50 units/mL of penicillin (Invitrogen) and $50 \mu \mathrm{g} / \mathrm{mL}$ of streptomycin (Invitrogen). MCF-12A cells were grown in a 1:1 mixture of DMEM and Ham's F12 medium (PAA Laboratories $\mathrm{GmbH}$ ) containing 5\% horse serum (Invitrogen) with $20 \mathrm{ng} / \mathrm{mL}$ human epidermal growth factor (Invitrogen), $100 \mathrm{ng} / \mathrm{mL}$ cholera toxin (Sigma), $0.01 \mathrm{mg} / \mathrm{mL}$ bovine insulin (Sigma) and $500 \mathrm{ng} / \mathrm{mL}$ hydrocortisone, 95\% (Sigma). All cultures were incubated at $37{ }^{\circ} \mathrm{C}$ in an atmosphere of $5 \% \mathrm{CO}_{2}$ and $95 \%$ air.

\subsection{Cytotoxic Assay}

The MTT assay was used for measuring toxicity as previously described [18,19]. Briefly, cells were seeded in 96-well plates overnight. After $72 \mathrm{~h}$ of incubation with crude extracts, the cells were rinsed with $1 \mathrm{X}$ PBS and incubated with $100 \mu \mathrm{L}$ of $0.5 \mathrm{mg} / \mathrm{mL}$ MTT at $37{ }^{\circ} \mathrm{C}$. After $30 \mathrm{~min}$ of incubation, the dark blue crystals of formazan (MTT metabolites) were dissolved with $100 \mu \mathrm{L}$ of DMSO and incubated at $37^{\circ} \mathrm{C}$ for $30 \mathrm{~min}$. The level of reduced MTT was determined by measuring the difference in absorbance at 570 and $650 \mathrm{~nm}$ using a microplate reader (Spectra Max M5, Molecular Devices). According to the U.S. NCI plant screening program, a crude extract is generally considered to have in vitro cytotoxic activity with an IC50 value $\leq 20 \mu \mathrm{g} / \mathrm{mL}$ [19].

\subsection{DNA Fragmentation}

The cells were incubated with an IC50 concentration of Fraction CE for 7 days. The treated cells were collected every day by trypsinization. DNA was extracted once, with an equal volume of phenol:chloroform:isoamyl alcohol (25:24:1) and once with chloroform:isoamyl alcohol (24:1). The DNA was precipitated with a two-thirds volume of cold isopropanol followed by centrifugation. The DNA pellet was washed once in $70 \%$ ethanol and resuspended in deionized water containing $0.1 \mathrm{mg} / \mathrm{mL}$. DNA was analyzed by $1.5 \%$ agarose gel electrophoresis. 


\subsection{Statistical Analysis}

Student's $t$-test was used to analyze intergroup differences. Experiments were repeated at least three times, and data are represented as the mean \pm SD. A $p$-value of less than 0.05 was considered to be statistically significant.

\section{Results}

\subsection{The Cytotoxic Effect of Crude Extracts from P. cubeba on Breast Cancer Cell Lines}

Both solvents, dichloromethane and methanol, were used to extract compounds from P. cubeba seeds, and MTT was used to determine their cytotoxic effects. After treatment, methanolic crude extract represented effects on MCF-7 and MDA-MB-468 with IC50 values of $22.31 \pm 0.83 \mu \mathrm{g} / \mathrm{mL}$ and $21.84 \pm 1.60 \mu \mathrm{g} / \mathrm{mL}$, respectively, whereas the dichloromethane crude extract demonstrated a weak effect on all cell lines. Both extracts showed non-cytotoxicity to normal breast cells (Table 1). The results suggest that the optimal solvent to extract the effective compounds was methanol.

Table 1. Cytotoxic effects of dichloromethane and methanolic crude extracts on three breast cancer cell lines.

\begin{tabular}{ccccc}
\hline \multirow{2}{*}{ Compound } & \multicolumn{4}{c}{ IC $_{\mathbf{5 0}}$ Value \pm SD $(\boldsymbol{\mu g} / \mathbf{m L})$} \\
\cline { 2 - 5 } & MCF-7 & MDA-MB-468 & MDA-MB-231 & MCF-12A \\
\hline Methanolic crude extract & $22.31 \pm 0.83$ & $21.84 \pm 1.60$ & $65.12 \pm 5.98$ & $>80$ \\
Dichloromethane crude extract & $62.20 \pm 0.55$ & $54.81 \pm 0.13$ & $35.71 \pm 5.73$ & $>80$ \\
\hline
\end{tabular}

\subsection{The Separation of Crude Extract by Column Chromatography}

The structure of methanolic crude extract was analyzed by ${ }^{1} \mathrm{H}-\mathrm{NMR}$. The ${ }^{1} \mathrm{H}-\mathrm{NMR}$ profile represented long chain hydrocarbons (data not shown). Then, the methanolic crude extract from $P$. cubeba was separated by column chromatography using silica gel and eluted with increasing proportions of hexane, dichloromethane and methanol. The fractions that had a similar profile on the TLC plate were pooled together. The separation showed six different fractions. These six fractions, labeled $\mathrm{A}$ to $\mathrm{F}$ for identification, were evaporated and tested for cytotoxic activity on breast cell lines. Fraction $\mathrm{C}$ proved to be the most effective fraction and was then selected to analyze the structure by ${ }^{1} \mathrm{H}-\mathrm{NMR}$ and further purified by column chromatography. The ${ }^{1} \mathrm{H}-\mathrm{NMR}$ profile showed that Fraction $\mathrm{C}$ was long chain hydrocarbons (Figure 1A). After separation, Fraction $\mathrm{C}$ showed seven different sub-fractions, labeled CA to CG. The most effective fraction was CE, and its ${ }^{1} \mathrm{H}-\mathrm{NMR}$ profile indicated the presence of long chain hydrocarbons (Figure 1B). 
A

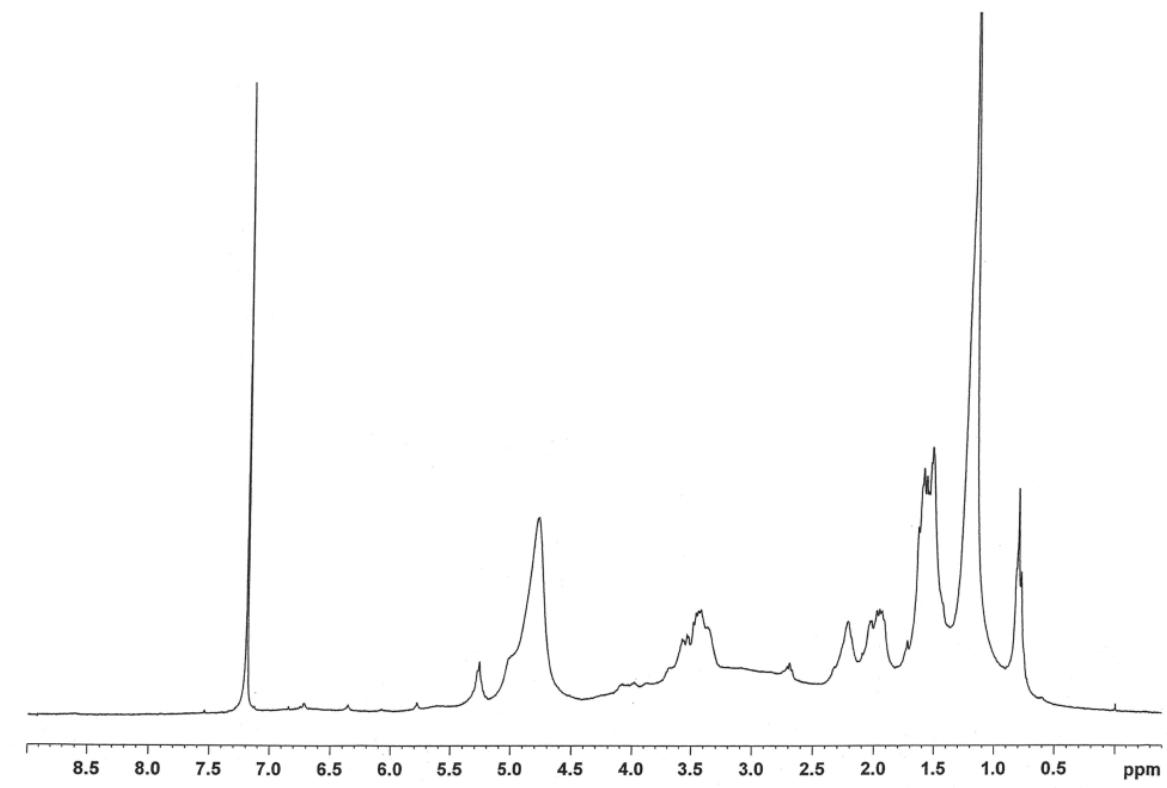

B

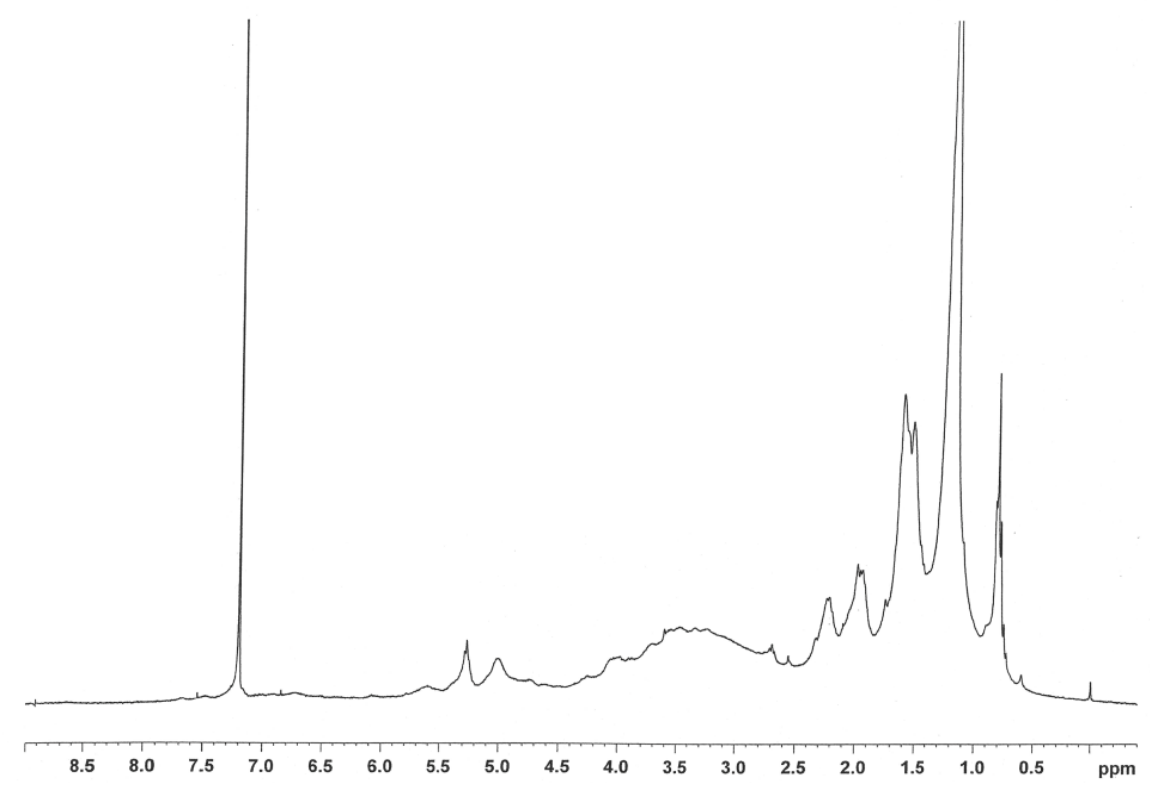

Figure 1. The ${ }^{1} \mathrm{H}-\mathrm{NMR}$ spectra of (A) Fraction C and (B) Fraction CE.

\subsection{Cytotoxicity Effect of the Fractions Separated from P. cubeba}

The methanolic crude extract was fractionated using column chromatography on silica gel. Six fractions (A to F) were obtained and tested for cytotoxic activity on MDA-MB-468 cell lines. Then, five fractions (B to F), which had demonstrated a cytotoxic effect, were selected to test for cytotoxic activity on breast cell lines. Fraction $\mathrm{C}$ showed the most cytotoxic effect on the three breast cancer cell lines, MCF-7, MDA-MB-468 and MDA-MB-231, with IC50 values of $2.72 \pm 0.03 \mu \mathrm{g} / \mathrm{mL}, 3.77 \pm 0.43 \mu \mathrm{g} / \mathrm{mL}$ and $4.03 \pm 0.88 \mu \mathrm{g} / \mathrm{mL}$, respectively. The IC50 values of the five fractions are shown in Table 2. Then, Fraction $\mathrm{C}$ was tested for cytotoxic activity on normal cell lines (MCF-12A) and showed an IC50 value of $13.69 \pm 2.36 \mu \mathrm{g} / \mathrm{mL}$. Next, Fraction $\mathrm{C}$ was separated into seven fractions (CA to CG) and the cytotoxicity tests repeated with these lines. Fraction CE exhibited a strong effect on MCF-7, MDA-MB-468 
and MCF-12A with IC50 values of $2.69 \pm 0.09 \mu \mathrm{g} / \mathrm{mL}, 2.97 \pm 0.15 \mu \mathrm{g} / \mathrm{mL}$ and $2.91 \pm 0.12 \mu \mathrm{g} / \mathrm{mL}$, respectively. Surprisingly, Fraction CE demonstrated less toxicity to normal L929 cells with an IC50 value of $4.17 \pm 0.77 \mu \mathrm{g} / \mathrm{mL}$ (Table 3). As shown in Figure 2, treatment with $5 \mu \mathrm{g} / \mathrm{mL}$ of Fraction CE for $72 \mathrm{~h}$ resulted in significant increase in inhibition of cell proliferation on MCF-7, MDA-MB-468 and MCF-12A cells, as compared with L929 cells ( $p<0.05)$.

Table 2. The IC50 values of six fractions isolated from the methanolic crude extract.

\begin{tabular}{ccccc}
\hline \multirow{2}{*}{ Compound } & \multicolumn{4}{c}{ IC $_{\mathbf{5 0}}$ Value \pm SD $(\boldsymbol{\mu g} / \mathbf{m L})$} \\
\cline { 2 - 5 } & MCF-7 & MDA-MB-468 & MDA-MB-231 & MCF-12A \\
\hline Fraction B & $10.46 \pm 1.28$ & $12.90 \pm 1.64$ & $17.54 \pm 1.72$ & ND \\
Fraction C & $2.72 \pm 0.28$ & $3.77 \pm 0.43$ & $4.03 \pm 0.88$ & $13.69 \pm 2.36$ \\
Fraction D & $7.09 \pm 0.13$ & $10.16 \pm 1.00$ & $20.45 \pm 0.48$ & ND \\
Fraction E & $4.37 \pm 1.05$ & $7.05 \pm 2.76$ & $13.48 \pm 1.65$ & ND \\
Fraction F & $15.53 \pm 0.15$ & $26.52 \pm 0.61$ & $46.69 \pm 6.84$ & ND \\
\hline
\end{tabular}

ND $=$ not determined.

Table 3. The IC 50 values of seven fractions isolated from Fraction C.

\begin{tabular}{cccccc}
\hline \multirow{2}{*}{ Compound } & \multicolumn{5}{c}{ IC $_{\mathbf{5 0}}$ Value \pm SD $(\boldsymbol{\mu g} / \mathbf{m L})$} \\
\cline { 2 - 5 } & MCF-7 & MDA-MB-468 & MDA-MB-231 & MCF-12A & L929 \\
\hline Fraction CA & $>80$ & $47.21 \pm 4.51$ & $>80$ & ND & $>80$ \\
Fraction CB & $61.70 \pm 6.61$ & $23.10 \pm 1.99$ & $35.97 \pm 0.54$ & ND & $>80$ \\
Fraction CC & $>80$ & $58.56 \pm 2.50$ & $>80$ & ND & $>80$ \\
Fraction CD & $>80$ & $22.04 \pm 2.57$ & $45.03 \pm 5.27$ & ND & $>80$ \\
Fraction CE & $2.69 \pm 0.09$ & $2.97 \pm 0.15$ & $3.98 \pm 0.12$ & $2.91 \pm 0.15$ & $4.17 \pm 0.77$ \\
Fraction CF & $25.95 \pm 3.24$ & $26.62 \pm 4.03$ & $32.68 \pm 2.09$ & ND & $55.49 \pm 0.91$ \\
Fraction CG & $>80$ & $>80$ & $>80$ & ND & $>80$ \\
\hline
\end{tabular}

ND $=$ not determined.

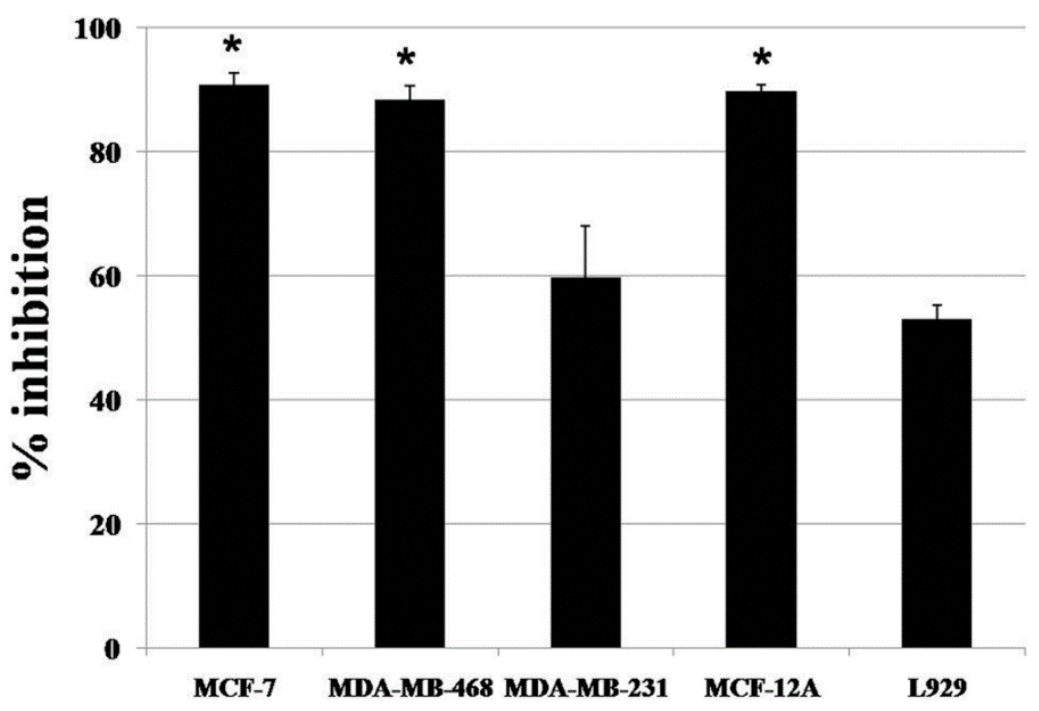

Figure 2. The effect of $5 \mu \mathrm{g} / \mathrm{mL}$ Fraction CE on MCF-7, MDA-MB-468, MDA-MB-231, MCF-12A and L929 cells after an exposure time of $72 \mathrm{~h}$. The values are expressed as the means \pm S.D. $(n=3) .{ }^{*} p<0.05$ versus normal L929 cells. 


\subsection{The Fractions CE Induced DNA Fragmentation on Breast Cancer Cell Lines}

A DNA fragmentation assay was used to determine whether the action of Fraction CE was associated with apoptosis or not. As shown in Table 3 and Figure 2, Fraction CE was strongly effective on three cell types. In this experiment, all tested cell lines were incubated with Fraction $\mathrm{CE}$ at the IC50 concentration. DNA fragmentation was found on MCF-7, MDA-MB-468, MDA-MB-231 and L929 cells at 2, 3, 4 and 7 days after exposure (Figure 3). In the MCF-7 cells, the ladder pattern was observed for a maximum of 3 days because all cells died. However, the formation of a DNA ladder was not observed in the MCF12A cells. Therefore, the cytotoxic effect of Fraction CE was selective for breast cancer cell lines and mediated through the induction of apoptosis.

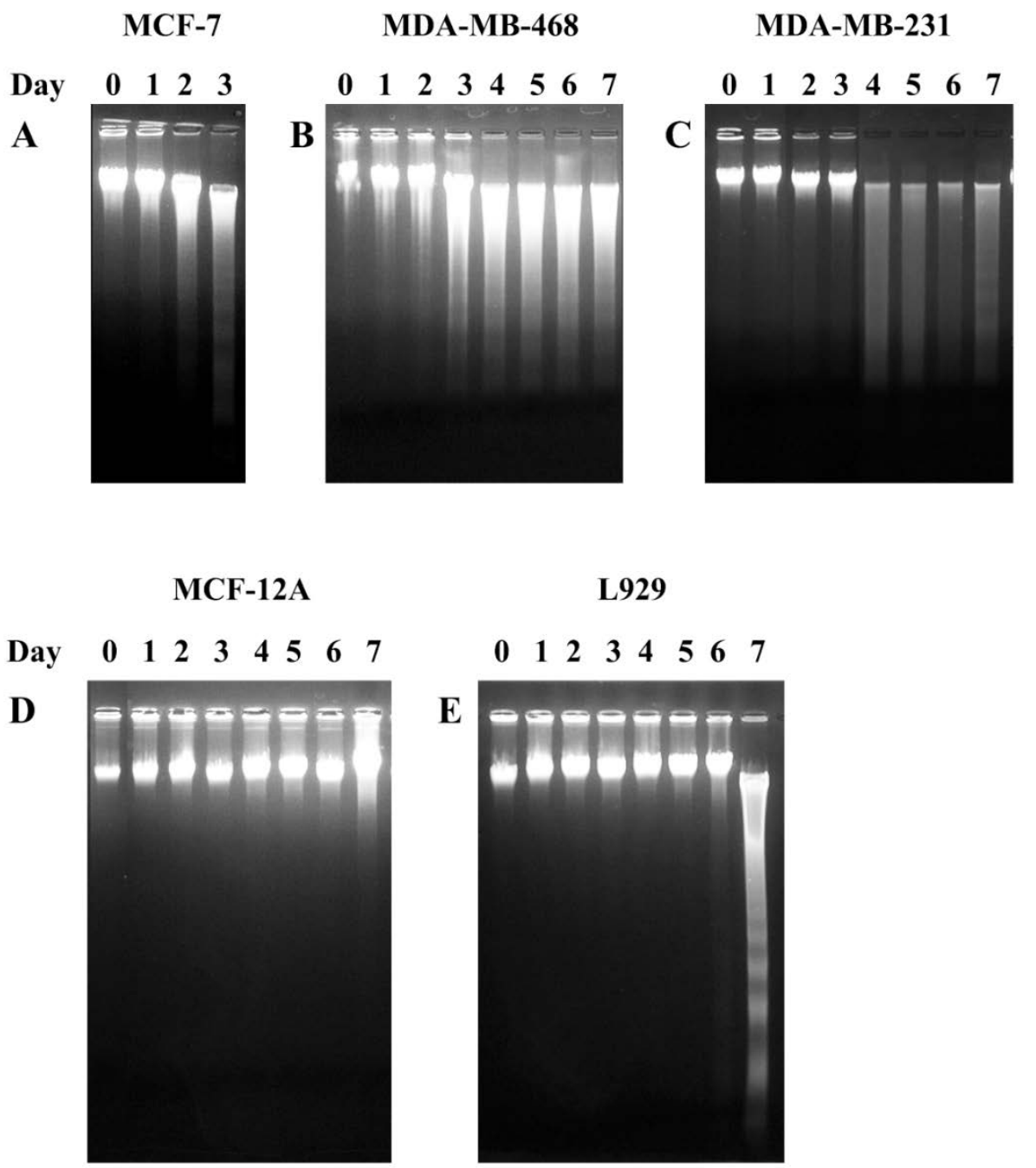

Figure 3. Analysis of DNA fragmentation induced by Fraction CE of P. cubeba in five cell lines. Cells were treated for seven days with Fraction CE, and DNA fragmentation was assessed by $1.5 \%$ agarose gel electrophoresis and ethidium bromide staining. Fraction $\mathrm{CE}$ was used to treat (A) MCF-7; (B) MDA-MB-468 (C) MDA-MB-231; (D) MCF-12A and (E) $\mathrm{L} 929$ with $2.69 \mu \mathrm{g} / \mathrm{mL}, 2.97 \mu \mathrm{g} / \mathrm{mL}, 3.98 \mu \mathrm{g} / \mathrm{mL}, 2.91 \mu \mathrm{g} / \mathrm{mL}$ and $4.17 \mu \mathrm{g} / \mathrm{mL}$, respectively. The data are representative of three independent experiments carried out under the same conditions. 


\section{Discussion}

In our study, we used methanol and dichloromethane to extract plant compounds because these two solvents have different polarities. Methanol has a high polarity, while dichloromethane has a low polarity. Therefore, extraction with solvents of different polarities should give different substances. In the extraction procedure, methanolic and dichloromethane extracts were dried on a rotary evaporator until the extracts become solid, then the extracts were dissolved in DMSO. DMSO was used as the control group, and the IC50 value from this group was set as the background. Stock solutions of the extracts were prepared in DMSO at high concentrations (approximately $100 \mathrm{mg} / \mathrm{mL}$ ) to make sure that the final concentrations of DMSO were not more than $0.2 \%$ and not toxic to the cells. Therefore, we can conclude that any cytotoxic effects were due to the compound and not the solvent. Moreover, our results demonstrated that the methanol extract was more effective than the dichloromethane extract, in terms of cytotoxic properties. However, Nahak and Sahu reported that the ethanol extract of $P$. cubeba had a higher antioxidant activity than both methanol and aqueous extracts and was also higher than an ethanol extract of $P$. nigrum [13]. Phenolic compounds, such as phenolic acids, flavonoids, quinones, coumarins, lignans, stilbenes and tannins, are rich in antioxidant properties [20,21]. These antioxidant compounds possess anti-inflammatory, anti-atherosclerotic, anti-tumor, anti-mutagenic, anti-carcinogenic, anti-bacterial and anti-viral activities [22-24]. In addition, Cai and co-worker reported that total phenolic content of Chinese medicinal plants showed a positive significant linear relationship with antioxidant activity [25].

Methanolic crude extract was separated by column chromatography and gave six fractions (A to F). Fraction $\mathrm{C}$ exhibited the most cytotoxic effect on breast cancer cell lines. Therefore, Fraction $\mathrm{C}$ was separated into seven fractions (CA to CG). Finally, Fraction CE demonstrated the strongest cytotoxic effect on three breast cancer cell lines. ${ }^{1} \mathrm{H}-\mathrm{NMR}$ profiles of these most effective extracts of the methanolic crude extracts, Fractions $\mathrm{C}$ and CE, showed that these were long chain hydrocarbons (Figure 1). In a previous study, the percentage of essential oil of some Piper species has been reported, for example $1.6 \%$ of $P$. attenuatum berries, $0.75 \%$ of $P$. attenuatum leaf, $1.0 \%$ of $P$. nigrum leaf and $14.5 \%$ of P. cubeba berries. P. cubeba berry oil contains $32 \%$ monoterpenes, $68 \%$ sesquiterpenes and high polar compounds. The major sesquiterpene hydrocarbons are $\beta$-elemene (7\%) and $\beta$-cubebene (6\%). The major monoterpene hydrocarbon is $\beta$-pinene (18\%) [26]. However, we cannot conclude that our long chain hydrocarbons were an essential oil, because these were an unpurified fraction and need to be further purified to obtain the pure compound that has the anti-cancer activity. Essential oils from Piper demeraranum and Piper duckei inhibit the growth of the promastigote form of Leishmania amazonensis and Leishmania guyanensis [27]. Yam and co-worker reported that P9605, an extract of P. cubeba seeds, suppressed growth on PC-3 prostate cancer cell lines. They hypothesized that this compound could be cubebin [10]. Moreover, Perazzo and colleagues also reported an anti-inflammation activity from the crude aqueous-alcoholic extract of $P$. cubeba, which again they thought was probably due to cubebin [7]. Cubebin is a dibenzylbutirolactone lignan that shows many biological activities [28], including anti-proliferation [29] and anti-inflammation [15].

Here, we used one normal fibroblast, one normal breast and three breast cancer cell lines that had difference characteristics. MCF-12A is the normal breast cell line. This cell is very difficult to culture. Therefore, we designed our study to test only extracts that are known to show high toxicity with breast 
cancer cell lines and used L929 as a representative of a normal cell. Mouse fibroblast L929 is a normal cell line, which is recommended by international standards for the testing of medical devices [30] and responds more sensitively than primary cells [31]. A plant extract that will act successfully as an anti-cancer drug should kill cancer cells without causing excessive damage to normal cells, such as L929. L929, MCF-7 and MCF-12A cells are p53 wild-types, while MDA-MB-468 and MDA-MB-231 cells are p53 mutations [32]. Furthermore, MCF-7 cells are estrogen-receptor (ER) positive and classified as low-grade and luminal type. MDA-MB-468 and MDA-MB-231 cells are ER negative and classified as high-grade and basal type [33]. Our results showed that Fraction CE had more cytotoxic effects on MCF-7, MCF-12A and MDA-MB-468 than MDA-MB-231, a high-grade cancer. Surprisingly, Fractions CA to CG appeared less toxic in normal fibroblast cells than breast cell lines (Table 3). These results suggest that all fractions were more selective for breast cells than normal cells.

One of the biochemical hallmarks of apoptosis is degradation of DNA by endogenous DNAses, which cut the internucleosomal regions into DNA fragments of 180-200 base pairs. The DNA fragmentation forms a ladder pattern that can be used to distinguish between apoptosis and necrosis [34,35]. This phenomenon can be generally detected by agarose gel electrophoresis, as shown in Figure 3. Here, our results showed that the DNA ladders of MCF-7, MDA-MB-468, MDA-MB-231 and L929 cells treated with Fraction CE were observed within seven days. In contrast, fragmented DNA was not observed in MCF-12A cells. Therefore, DNA ladder formation indicated that the cytotoxic effect of Fraction CE caused inhibition in the growth of breast cancer and normal fibroblast cells through apoptosis. Fraction $\mathrm{CE}$ also inhibited growth in normal breast cells, but not to the point of death through apoptosis. In the L929 cells, Fraction CE inhibited cell growth within six days and induced cell death on Day 7 after incubation. Although treated L929 cells showed DNA ladders at Day 7, the incubation time was longer and the dose was higher than in the breast cancer cell lines. Thus, our Fraction CE seemed to be safe for normal cells. However, further experiments are needed to evaluate the specific molecules in the apoptotic pathway. Our previous study showed that $P$. nigrum extract exhibited a cytotoxic effect and induced DNA fragmentation on a breast cancer cell line [19]. In addition, other studies have found that an ethanolic extract of Mimosa caesalpiniifolia leaves and an aqueous extract of Plinia edulis leaves caused cytotoxicity and induced cell death and DNA fragmentation in MCF-7 cells, via a mechanism that seemed to use the apoptosis pathway [36,37].

\section{Conclusions}

In conclusion, Fraction CE from $P$. cubeba fruit exhibited cytotoxic activity against breast cancer cells and normal breast cells and lower toxicity against normal fibroblast cells. The cytotoxic effect of this fraction inhibited cell growth and appears to have induced apoptosis in MCF-7, MDA-MB-468, MDA-MB-231 and L929 cells. Further purification to obtain a potentially active and pure compound will be undertaken in the future.

\section{Acknowledgments}

This work was financially supported by the Faculty of Medicine, Prince of Songkla University. 


\section{Author Contributions}

Designed the experiments: P.G., M.M., Y.S. Performed the experiments: P.G., M.M., Y.S. Analyzed and discussed the data: P.G., M.M., Y.S. Wrote the manuscript: P.G., M.M.

\section{Conflicts of Interest}

The authors declare no conflicts of interest.

\section{References}

1. Siegel, R.; Ma, J.; Zou, Z.; Jemal, A. Cancer Statistics, 2014. CA: Cancer J. Clin. 2014, 64, 9-29.

2. Cancer Research UK. Side Effects of Cancer Drugs. Available online: http://cancerhelp.cancerresearchuk.org/about-cancer/treatment/cancer-drugs/side-effects (accessed on 14 February 2013).

3. Raguz, S.; Yague, E. Resistance to chemotherapy: New treatments and novel insights into an old problem. Br. J. Cancer 2008, 99, 387-391.

4. Sastroamidjojo, S. ObatAsli Indonesia; Dian Rakyat: Jakarta, Indonesia, 1997; pp. 38-291.

5. Ahmad, Q.Z.; Jahan, N.; Ahmad, G.; Tajuddin. Nephroprotective effect of Kabab chini (Piper cubeba) in gentamycin-induced nephrotoxicity. Saudi J. Kidney Dis. Transplant. 2012, 23, 773-781.

6. Choi, E.M.; Hwang, J.K. Investigations of anti-inflammatory and anti-nociceptive activities of Piper cubeba, Physalis angulata and Rosa hybrid. J. Ethnopharmacol. 2003, 89, 171-175.

7. Perazzo, F.F.; Rodrigues, I.V.; Maistro, E.L.; Souza, S.M.; Nanaykkara, N.P.D.; Bastos, J.K.; Carvalho, J.C.T.; de Souza, G.H.B. Anti-inflammatory and analgesic evaluation of hydroalcoholic extract and fractions from seeds of Piper cubeba L. (Piperaceae). Pharmacogn. J. 2013, 5, 13-16.

8. Bodiwala, H.S.; Singh, G.; Singh, R.; Dey, C.S.; Sharma, S.S.; Bhutani, K.K.; Singh, I.P. Antileishmanial amides and lignans from Piper cubeba and Piper retrofragtum. J. Nat. Med. 2007, 61, 418-421.

9. Junqueira, A.P.F.; Perazzo, F.F.; Souza, G.H.B.; Maistro, E.L. Clastogenicity of Piper cubeba (Piperaceae) seed extract in an in vivo mammalian cell system. Gen. Mol. Biol. 2007, 30, 656-663.

10. Yam, J.; Kreuter, M.; Drewe, J. Piper cubeba targets multiple aspects of the androgen-signalling pathway. A potential phytotherapy against prostate cancer growth? Planta Med. 2008, 74, 33-38.

11. Januario, A.H.; Rodrigues Filho, R.; Pietro, R.C.L.R.; Kashima, S.; Sato, D.N.; Franca, S.C. Antimycobacterial physalins from Physalis angulata L. (Solanaceae). Phytother. Res. 2002, 16, 445-448.

12. Usia, T.; Iwata, H.; Hiratsuka, A.; Watabe, T.; Kadota, S.; Tezuka, Y. CYP3A4 and CYP2D6 inhibitory activities of Indonesian medicinal plants. Phytomedicine 2006, 13, 67-73.

13. Nahak, G.; Sahu, R.K. Phytochemical evaluation and antioxidant activity of Piper cubeba and Piper nigrum. J. Appl. Pharm. Sci. 2011, 1, 153-157.

14. Elfahmi; Ruslan, K.; Batterman, S.; Bos, R.; Kayser, O.; Woerdenbag, H.J.; Quax, W.J. Lignan profile of Piper cubeba, an Indonesian medicinal plant. Biochem. Syst. Ecol. 2007, 35, 397-402. 
15. Bastos, J.K.; Carvalho, J.C.T.; Souza, G.H.B.; Pedrazzi, A.H.P.; Sarti, S.J.J. Anti-inflammatory activity of cubebin, a lignan from the leaves of Zanthoxylum naranjillo Griseb. J. Ethnopharmacol. 2001, 75, 279-282.

16. Silva, M.L.; Coimbra, H.S.; Pereira, A.C.; Almeida, V.A.; Lima, T.C.; Costa, E.S.; Vinholis, A.H.; Roya, V.A.; Silva, R.; Filho, A.A.; et al. Evaluation of Piper cubeba extract, (-)-cubebin and its semi-synthetic derivatives against oral pathogens. Phytother. Res. 2007, 21, 420-422.

17. De Rezende, A.A.; Munari, C.C.; de Oliveira, P.F.; Ferreira, N.H.; Tavares, D.C.; E Silva, M.L.A.; Rezende, K.C.S.; Spano, M.A. A comparative study of the modulatory effects of (-)-cubebin on the mutagenicity/recombinogenicity induced by different chemical agents. Food Chem. Toxicol. 2013, 55, 645-652.

18. Lee, C.C.; Houghton, P. Cytotoxic of plants from Malaysia and Thailand used traditionally to treat cancer. J. Ethnopharmacol. 2005, 100, 237-243.

19. Sriwiriyajan, S.; Ninpesh, T.; Sukpondma, Y.; Nasomyon, T.; Graidist, P. Cytotoxicity screening of plants of genus Piper in breast cancer cell lines. Trop. J. Pharm. Res. 2014, 13, 921-928.

20. Zheng, W.; Wang, S.Y. Antioxidant activity and phenolic compounds in selected herbs. J. Agric. Food Chem. 2001, 49, 5165-5170.

21. Cotelle, N.; Bernier, J.L.; Catteau, J.P.; Pommery, J.; Wallet, J.C.; Gaydou, E.M. Anti-oxidant properties of hydroxy-flavones. Free Radic. Biol. Med. 1996, 20, 35-43.

22. Mitscher, L.A.; Telikepalli, H.; McGhee, E.; Shankel, D.M. Natural antimutagenic agents. Mutat. Res. 1996, 350, 142-143.

23. Owen, R.W.; Giacosa, A.; Hull, W.E.; Haubner, R.; Spiegelhalder, B.; Bartsch, H. The antioxidant/anticancer potential of phenolic compounds isolated from olive oil. Eur. J. Cancer 2000, 36, 1235-1247.

24. Sala, A.; Recio, M.; Giner, R.M.; Manez, S.; Tournier, H.; Schinella, G.; Rios, J.L. Anti-inflammatory and antioxidant properties of Helichrysum italicum. J. Pharm. Pharmacol. 2002, 54, 365-371.

25. Cai, Y.; Luo, Q.; Sun, M.; Corke, H. Antioxidant activity and phenolic compounds of 112 traditional Chinese medicinal plants associated with anticancer. Life Sci. 2004, 74, 2157-2184.

26. Sumathykutty, M.A.; Madhusudana Rao, J.; Padmakumari, K.P.; Narayanan, C.S. Essential oil constituents of some Piper species. Flavour Fragr. J. 1999, 14, 279-282.

27. Moura do Carmo, D.F.; Amaral, A.C.; Machado, G.M.; Leon, L.L.; Silva, J.R. Chemical and biological analyses of the essential oils and main constituents of Piper species. Molecules 2012, 17, 1819-1829.

28. Da Silva, R.; de Souza, G.H.; da Silva, A.A.; de Souza Vde, A.; Pereira, A.C.; Royo, V.A.; Silva, M.L.; Donate, P.M.; de Matos Araujo, A.L.; Carvalho, J.C.; et al. Synthesis and biological activity evaluation of lignan lactones derived from (-)-cubebin. Bioorganic Med. Chem. Lett. 2005, 15, 1033-1037.

29. Niwa, A.M.; Marcarini, J.C.; Sartori, D.; Maistro, E.L.; Mantovani, M.S. Effects of (-)-cubebin (Piper cubeba) on cytotoxicity, mutagenicity and expression of p38 MAP kinase and GSTa2 in a hepatoma cell line. J. Food Compos. Anal. 2013, 30, 1-5.

30. International Organization for Standardization, ISO 10993-5. Biological Evaluation of Medical Devices-Part 5. Tests for Cytotoxicity: In vitro Methods; ISO: Geneve, Switzerland, 1992. 
31. Schedle, A.; Samorapoompichit, P.; Rausch-Fan, X.H.; Franz, A.; Fureder, W.; Sperr, W.R.; Sperr, W.; Ellinger, A.; Slavicek, R.; Boltz-Nitulescu, G.; et al. Response of L-929 fibroblasts, human gingival fibroblasts, and human tissue mast cells to various metal cations. J. Dent. Res. 1995, 74, 1513-1520.

32. Lacroix, M.; Toillon, R.A.; Leclercq, G. p53 and breast cancer, an update. Endocr. Relat. Cancer 2006, 13, 293-325.

33. Kenny, P.A.; Lee, G.Y.; Myers, C.A.; Neve, R.M.; Semeiks, J.R.; Spellman, P.T.; Lorenz, K.; Lee, E.H.; Barcellos-Hoff, M.H.; Petersen, O.W.; et al. The morphologies of breast cancer cell lines in three-dimensional assays correlate with their profiles of gene expression. Mol. Oncol. 2007, 1, 84-96.

34. Saraste, A.; Pulkki, K. Morphologic and biochemical hallmarks of apoptosis. Cardiovasc. Res. 2000, 45, 528-537.

35. Elmore, S. Apoptosis: A review of programmed cell death. Toxicol. Pathol. 2007, 35, 495-516.

36. Carvalho, A.J.S.; Ishikawa, T.; Gouvea, C.M.C.P. Aqueous extract of Plinia edulis leaves: Antioxidant activity and cytotoxicity to human breast cancer MCF-7 cell line. S. Afr. J. Bot. 2012, 81, 1-7.

37. Silva, M.J.D.; Carvalho, A.J.S.; Rocha, C.Q.; Vilegas, W.; Silva, M.A.; Gouvea, C.M.C.P. Ethanolic extract of Mimosa caesalpiniifolia leaves: Chemical characterization and cytotoxic effect on human breast cancer MCF-7 cell line. S. Afr. J. Bot. 2014, 93, 64-69.

(C) 2015 by the authors; licensee MDPI, Basel, Switzerland. This article is an open access article distributed under the terms and conditions of the Creative Commons Attribution license (http://creativecommons.org/licenses/by/4.0/). 